\title{
Prevalence of Orthorexia in Diabetic Patients
}

\section{Cuneyd Anil, Gozde Aritici, Hacer Ari, Neslihan Bascil Tutuncu}

\section{Baskent University, Faculty of Medicine, Department of Endocrinology and Metabolism}

\section{Objectives:}

- Orthorexia nervosa (ON) is an eating disorder, characterized by an obsession with avoiding foods perceived to be unhealthy (1).

-Though it has not been recognized as a pathological entity in Diagnostic and Statistical Manual of Mental Disorders -IV yet, interest in the condition and its prevalence have been increasing recently $(1,2)$.

- ON has been studied in various populations in Turkey; however, no study carried out in cases with Diabetes Mellitus (DM) was noticed (3-6).

- This study aimed to determine the prevalence and risk factors of orthorexia in a group of patients with DM.
-134 (63 female) DM patients who admitted to the outpatient clinic of Department of Endocrinology of Baskent University were enrolled.

-Demographic information, educational status, diabetic history, care, and treatment, height, and weight of all cases were recorded.

- Ortho-15 Questionnaire was applied to all participants. Each patient can score minimum 15, maximum 60 points from this test. Those scoring 40 points and less are accepted to be orthorectic (1).

Table 1. The distribution of frequency of orthorexia nervosa according to sex and educational status*

\begin{tabular}{|c|c|c|c|c|c|}
\hline \multirow[b]{3}{*}{ Sex } & \multicolumn{4}{|c|}{ Orthorexia Nervosa } & \multirow[b]{3}{*}{ Total } \\
\hline & \multicolumn{2}{|c|}{ Present } & \multicolumn{2}{|c|}{ Absent } & \\
\hline & Number & $\%$ & Number & $\%$ & \\
\hline Female & 7 & 11.1 & 56 & 88.9 & $63 / 100 \%$ \\
\hline Male & 11 & 15.5 & 60 & 84.5 & $71 / 100 \%$ \\
\hline \multicolumn{5}{|c|}{ Educational status } & \\
\hline Primary & 5 & 27.7 & 19 & 16.4 & \\
\hline Highschool & 4 & 22.3 & 33 & 28.4 & \\
\hline University & 8 & 44.4 & 53 & 45.7 & \\
\hline Post-graduate & 1 & 5.6 & 11 & 9.5 & \\
\hline Total & 18 & 100 & 116 & 100 & \\
\hline
\end{tabular}

\section{Resultis:}

- The mean age of the group was $59.9 \quad 11.7$ years.

- The Ortho-15 test revealed that the mean SD test score of the whole group was 35.44 .2 points; the minimum score being 25 , and the maximum 46 points.

- The frequency of ON in the study group was $13.4 \%$ (18/134 cases).

- ON displayed similar frequency in both sexes and educational status did not affect its occurrence (Table 1).

-No relation was determined between BMI and presence of orthorexia $(\mathrm{p}>0.05)$.

- The mean duration of diabetes of the whole group was 10.1 8.8 years and there was no relation between duration of diabetes and presence of $\mathrm{ON}$.

\section{Conclusions:}

- Like other eating disorders, orthorexia nervosa might lead to serious consequences in diabetic disorders.

-This study, probably the first performed in cases with Diabetes Mellitus, revealed that orthorexia nervosa was not frequent in this group of patients.

-Performing the test on larger groups making comparisons with non-diabetic controls may introduce different results.

\section{References:}

1.Koven NS, Abry AW. The clinical basis of orthorexia nervosa: emerging perspectives. Neuropsychiatr Dis Treat. 2015 Feb 18;11:385-94.

2015 Feb 18;11:385-94.
2. American Pscychiatric Association Diagnostic and Statistical Manal for Mental Disorders (4 th Ed.).

Washington, DC: American Psychiatric Association, 1994.

3. Asil E, Sürücüoğlu MS. Orthorexia Nervosa in Turkish Dietitians. Ecol Food Nutr. 2015 Jan 20:1-11. [Epub ahead of print] PubMed PMID: 25602930.

4. Fidan T, Ertekin V, Işikay S, Kirpinar I. Prevalence of orthorexia among medical students in Erzurum, Turkey. Compr Psychiatry. 2010 JanFeb;51(1):49-54.

Feb;51(1):49-54.
5. Aksoydan E, Camci N. Prevalence of orthorexia nervosa among Turkish performance artists. Eat Weight Disord. 2009 Mar;14(1):33-7.

6. Arusoğlu G, Kabakçi E, Köksal G Merdol TK. [Orthorexia nervosa and adaptation of ORTO-11 into Turkish].

Turk Psikiyatri Derg. 2008 Fall;19(3):283-91. Turkish. 